\title{
Covid-19 Pandemisi Sürecinde Seyahatten Kaçınma Niyetinin Karmaşıklık Bakış Açısı ile Analizi
}

\author{
Analysis of Travel Avoidance Intention from a Complexity Perspective During the Covid-19 Pandemic Process \\ Beykan ÇizEL*, İsmail Gökay KIRTIL**, Rabia ÇiZEL***, Volkan AŞKUN**** \\ * Prof. Dr., Turizm Fakültesi, Akdeniz Üniversitesi, Dumlupınar Bulvarı, 07070 Antalya / Türkiye. \\ E- posta: beykan@akdeniz.edu.tr \\ ORCID: 0000-0003-0474-9222 \\ ** (Sorumlu Yazar) Öğretim Görevlisi, Demre Dr. Hasan Ünal Meslek Yüksekokulu, Akdeniz Üniversitesi, 07570 Demre, Antalya, Türkiye. \\ E- posta: gokay@akdeniz.edu.tr \\ ORCID: 0000-0002-3520-9600 \\ *** Prof. Dr., İktisadi ve İdari Bilimler Fakültesi, Akdeniz Üniversitesi, Dumlupınar Bulvarı, 07070 Antalya, Türkiye. \\ E-posta: rabiacizel@akdeniz.edu.tr \\ ORCID: 0000-0002-6381-2503 \\ **** Öğretim Görevlisi, Demre Dr. Hasan Ünal Meslek Yüksekokulu, Akdeniz Üniversitesi, 07570 Demre, Antalya, Türkiye. \\ E-posta: volkanaskun@gmail.com \\ ORCID: 0000-0003-2746-502X
}

MAKALE BILGILERI

Makale işlem bilgileri:

Gönderilme tarihi: 15 Mart 2021

Düzeltme: 8 Temmuz 2021

Düzeltme: 20 A ̆̆ustos 2021

Kabul: 24 A ğustos 2021

Anahtar sözcükler: Kriz, Turist davranışı, Karmaşıklık Teorisi, fs QCA,

Covid-19, Seyahatten kaçınma niyeti.

\section{ARTICLE INFO}

Article history:

Submitted: 15 March 2021

Resubmitted: 8 July 2021

Resubmitted: 20 August 2021

Accepted: 24 August 2021

Key words: Crisis, Tourist behavior, Complexity Theory, fsQCA, Covid-19, Travel avoidance intention.

öz

Kriz ve afet dönemleri gibi sistemlerin olağan dinamiklerinden uzaklaștığı ve kaotik örüntüler sergilediği süreçlerde turistlerin seyahat niyetlerinde farklılıklar ortaya çıkabilmektedir. Bu çalışmanın amacı, Covid-19 gibi yüksek risk ve belirsizlik içeren bir dönemde yerli turistlerin seyahatten kaçınma niyetini karmaşıklık teorisi bakıs açısıla bir model içinde incelemektir. Araștırmanın çalıșma grubunda çevrimiçi anket vasıtasıyla ulașıIan 349 yerli turist yer almıștır. Veri toplama için kullanılan soru formunda demografik sorular hariç, toplam beş değişken yer almış ve her bir değişken üç soruyla ölçülmüştür. Bulanık küme nitel karşılaştırmalı analiz (fsQCA) yoluyla araștırma değișkenleri arasındaki asimetrik ilișkiler yedi konfigürasyon altında incelenmiștir. Bu konfigürasyonların farklı yaș, cinsiyet, eğitim düzeyi, medeni hal durumlarında ve farklı koșul değișkenleri bağlamında sonuç değişkeni üzerinde ne tür etkileri olduğu tartışılmıştır. Buna göre, pandemi sürecindeki hijyen ve ekonomik kaygıların turistlerin seyahatten kaçınma niyetini etkilediği saptanmıştır.

\begin{abstract}
In processes such as crisis and disaster periods, when systems move away from their usual dynamics and display chaotic patterns, differences in tourists' travel intentions may occur. The aim of this study is to examine the intention of domestic tourists to avoid travel in a time of high risk and uncertainty such as Covid-19 in a model with complexity theory. The study group of the research included 349 domestic tourists reached through an online survey. Accordingly, a total of five variables were included in the measurement model, excluding demographic questions, and each variable was measured with three questions. Asymmetric relationships between research variables were examined under seven configurations through fuzzy set qualitative comparative analysis (fsQCA). It is discussed what kind of effects these configurations have on the outcome variable in the context of different age, gender, education level, marital status and different condition variables. Accordingly, it has been determined that hygiene and economic concerns during the pandemic process affect the intention of tourists to avoid travel.
\end{abstract}

\section{GiRiş}

Turizm, soyut ve deneyimsel doğası gereği, öngörülemeyen olasılıklar, riskler ve belirsizliklerle örülü bir sektördür. Kriz dönemlerinde turist davranışının altında yatan sebepler bu belirsizlikler ve risklere dair algılardır. Karar vermeye ilişkin geleneksel modellerin bu dönemlerdeki turist davranışını açıklamada yetersiz kalması yüzünden (Sönmez ve Graefe 1998), kriz duru- 
muna özel davranış çalışmaları yapılmaktadır (Cahyanto vd. 2016; Papatheodorou ve Pappas 2017; Das ve Tiwari 2020; Pappas ve Glyptou 2021). Pandemi gibi kriz oluşturan durumların turist davranışına olası etkileri kapsamlı ve derinlemesine incelendikçe tutumların ardında yatan sebepler ortaya çıkarılabilecektir. Nitekim Kock vd. (2020) Covid-19 döneminde yapılan turizm araştırmalarının, genellikle, rakamlar üzerinde yoğunlaşan betimsel araştırmalar olduklarına dikkat çekmiş ve pandemi sürecinde turist davranışının derinlemesine ve teori temelli araştırılmasını önermiştir.

Covid-19 pandemisi, ortaya çıkışı ve etkileri açısından doğrusal olmayan eğilimler sergileyen, yüksek belirsizlik içeren, dolayısıyla, öngörülemeyen bir süreçtir. Karmaşıklık teorisi bu tarz süreçleri incelemede doğrusal yöntemlere nazaran daha faydalı bir araç olarak önerilmektedir (Russell ve Faulkner 1999; Faulkner 2001; Manson 2001; Ritchie ve Jiang 2019). Turizmdeki krizlere karmaşıklık teorisi perspektifiyle yaklaşmak krizin sürekli değişim halinde olan evrelerinin daha doğru anlaşılmasını ve yeni formlara evrilen turizm sistemlerinin tekrar yapilandırılmasını mümkün k1lacaktır (Reddy vd. 2020).

$\mathrm{Bu}$ araştırmada karmaşıklık teorisi bakış açısıyla turist davranışı analiz edilmiştir. Araştırma sürecinde öncelikli olarak Covid-19 dönemindeki turist davranışlarını incelemek amacıyla, kriz durumları ve salgın hastalıklarla ilgili çalışmalar incelenmiş (Reisinger ve Mavondo 2005; Cahyanto vd. 2016; Huang vd. 2020; Neuburger ve Egger 2020; Karabulut vd. 2020; Pappas ve Glyptou 2021) ve turistlerin seyahat davranışlarının altında yatan risk algıları, seyahatten kaçınma niyetini etkileyebilecek koşul değişkenleri olarak belirlenmiştir. Buna göre temizlik ve hijyen riskleri, ürün fiyat ve kalite riskleri, Covid-19 ciddiyet algısı ve turizm amaçlı harcanabilir gelir turistik davranışı etkileyebilecek değişkenler olarak araştırmaya dahil edilmiştir. Araştırmanın temel amacı Covid-19 sürecinde turistlerin seyahatten kaçınma niyetine etki eden koşul değişkenlerinin olası kombinasyonlarının asimetrik etkilerini bir model içinde inceleyerek seyahat davranışını analiz etmektir.

\section{ALANYAZIN TARAMASI}

Geçtiğimiz 50 yılda yaşanan kriz süreçleri (Ebola virüsü-1976, SARS virüsü-2003, Dünya Ekonomik Krizi-2007/2008, 11 Eylül Saldırıları-2001, MERS virüsü-2012 vb.) turizmin diş olaylara karş1 esnek olduğunu ve toparlanabildiğini göstermiş, ancak bu krizlerin hiçbiri küresel ekonomi üzerinde Covid-19 kadar yıkıcı etki göstermemiştir (Gössling vd. 2021). Önceki salgın hastaliklardan öğrenilen deneyimlerin Covid-19'un etkilerini öngörmede yetersiz kalması yüzünden (Karabulut vd. 2020), içinde bulunduğumuz kriz süreci farklı bakış açılarıyla ele alınmalıdır.

\section{Covid-19 Pandemisi Riski ve Seyahat Davranışı}

Kriz dönemlerinde destinasyon seçimleri ve seyahat kararları çeşitli risk ve belirsizlikler içinde verilmektedir. Sağlık, hijyen ve güvenliğe dair algılanan risklerin seyahat kararını etkilediği bilinirken (Sönmez ve Graefe 1998; Reisinger ve Mavondo 2005) bulaşıcı hastalıklar turistlerin seyahat planlarını değiştirmesine neden olan en güçlü risk faktörü olarak belirmektedir (Kozak vd. 2007). Ebola virüsü bağlamında yapılan bir çalışmada turistlerin algilanan seyahat risklerinin, hastalık hassasiyetlerinin ve hastalık hakkında bilgilerinin (algılanan öznel bilgi) seyahatten kaçınma davranışlarını tetiklediği görülürken, algilanan seyahat riskleri en güçlü seyahat engelleyici olarak öne çıkmıştır (Cahyanto vd. 2016). Ekonomik kriz gibi belirsizlik dönemlerinde turistlerin iş güvenceleri ve turizm amaçlı harcanabilir gelirlerinin seyahat kararlarını etkilediği görülürken (Papatheodorou ve Pappas 2017), tatil amaçlı devlet desteği, seyahat sigortası, iade edilebilir konaklama ve uçak bileti gibi destekler risk algılarını düşürmeye yardımcı olabilir.

Pandemi sürecinde yapılan risk algisı ve seyahat davranışı çalışmaları incelendiğinde, Covid-19 bulaşma ve öldürücülüğüne ilişkin ciddiyet algısı yüksek çıkan turistlerin seyahat niyetlerinin olumsuz etkilendiği görülmüştür. Ancak turistlerin kişisel farmakolojik olmayan yöntemlerle hastalıktan korunmaya çalıştıkları, bu yöntemlerin bulaşma ve enfeksiyon riskini bir nebze düşürüp seyahat niyetini olumlu etkilediği saptanmıştır (Das ve Tiwari 2020). Hastalık riskinin 
turistleri hastalık önleyici önlemler almaya yönelttiği ve bu önleyici davranışların seyahat tatmini hissini pekiştirdiği bilinirken (Huang vd. 2020); Covid-19 bağlamında turist karar verme sürecinde genel risk, fiyat, kalite, temizlik ve hijyen riskleri algılarının belirleyici olduğu araştırma modelleri tasarlanmıştır (Pappas ve Glyptou 2021).

Neuburger ve Egger (2020), turistleri Covid-19 algilarına, seyahat riski algilarına ve seyahat davranışlarına göre gruplara ayırmıştır. Her bir grubun farklı hassasiyetleri nedeniyle farklı seyahat davranışı geliştireceğini düşünmüşlerdir. Buna göre 'tedirgin' grup daha genç, daha az seyahat tecrübesi olan turistlerden oluşan, yüksek Covid-19 ve seyahat riski algisı sergileyen grup olmuştur. Bu grubun seyahat planı değiştirme veya iptal etme niyeti yüksektir. 'Rahat' grup daha yaşlı, daha fazla seyahat tecrübesi olan turistlerden oluşmuştur. Bu grup Covid-19 ve seyahat riski algısı en düşük olan turistlerden oluşmuş, seyahat planını değiştirme veya iptal etmeye en uzak olan grup olmuştur. Farklı turist tipleri ve turizm türleri bağlamında hastalık risklerine yönelik çalışmalar yapılması sektörün kriz durumlarına karşı esneklik kazanmasına yardımcı olabilir. Nitekim Hajibaba vd. (2015), yüksek risk yatkınlığına sahip, iç ve dış krizlere karşı dayanıklı yeni bir turist tipi önermiş, 'krize dayanıklı turist' kavramını alanyazına kazandırmıştır. $\mathrm{Bu}$ tip turist kriz sürecine rağmen rezervasyon yapmakta, iptal veya değişiklikten uzak durmaktadir.

Krizler sistemlerin olağan akışının bozulduğu, yüksek risk ve belirsizlik içeren dönemlerdir. Zenker ve Kock (2020), koronavirüs pandemisinin izole bir yönüne odaklanılmasını, yüksek karmaşıklık ve bağlantılılık ile başa çıkmak ve özellikle doğrusal olmayan ilişkileri ortaya çıkarmak için hem kaos teorisini hem de sistem teorisini kullanılmasını önermektedir.

\section{Covid-19 ve Karmaşıklık Teorisi}

İçinde bulunduğumuz pandemi süreci, belirli bir başlangıcı, ortası ve sonu olan doğrusal bir olaylar zincirinden ziyade süreç hakkında bildiklerimiz, bilmediklerimiz ve öğrendiklerimizle birlik- te ilerleyen, doğrusal olmayan bir kriz sürecidir (AON 2020). İlerleyişi itibariyle, beklenen değişimlerin ve sonuçların gözlemlenmesi yerine, örtük değişkenlerin ve öngörülemeyen ilişki ağlarının belirdiği kaotik bir yapı ortaya çıarmaktadir. Bu tarz durumlar sistemi tehdit edip, kritik eşiğin ötesine taşıdığında tüm sistem yok olabilir, kriz öncesi düzene yakın bir konfigürasyona geri gelebilir veya tamamen yeni ve daha güçlü bir konfigürasyon oluşabilir (Faulkner 2001).

Kaos ve karmaşıklık teorileri 20. yüzyılın sonlarında görelilik, kuantum ve evrim teorilerinden hareketle geliştirilmiş; doğanın, gezegenin, evrenin fraktal ve düzensiz olduğu genel kabulüyle ortaya çıkmıştır (Doll 2008). 'Kaos' ve 'karmaşıklık' kavramlarının birlikte kullanılması alanyazında karşılaşılan bir durumdur. 'Kelebek etkisi' kavramını alanyazına kazandıran matematikçi Lorenz'e (1993) göre iki kavram da aslında 'düzensizliği' ifade etmekte; kaos zamanda düzensizliğe, karmaşıklık ise uzay-mekansal düzensizliğe çıkarım yapmaktadır. Kaos, çalkantı ve dalgalanmaları sistemin doğal bir unsuru olarak görür. Bu noktada Lorenz (1993) kaosu karmaşık sistemlerin bir alt özelliği olarak görmüş, matematiksel modellerde yer alan ve genelde hata varyansı kabul edilip göz ardı edilen çok küçük değişikliklerin dalgalı, çelişkili ve beklenmedik sonuçlar doğurabileceğini keşfetmiştir. Bu küçük ve önemsiz görünen sapma ve değişiklikleri açıklamada doğrusal yöntemler yetersiz kalmaktadır. Nitekim Woodside (2013; 2014) araştırmalardaki hâkim paradigmanın, çoklu regresyon analizi ve yapısal eşitlik modeli gibi simetrik testlerle bir grup bağımsız değişkenin bağımlı değişken üzerindeki doğrusal etkilerinin incelenmesi olduğuna dikkat çekmiştir.

Simetrik bir ilişki izlenerek X'in Y üzerindeki pozitif veya negatif net etkisini göstermek yerine, $X^{\prime}$ in $Y$ üzerindeki etkilerini farklı kombinasyon koşullarında göstermek çalışmaya değer katacaktır (Woodside 2013). Araştırma boyunca arayışında olunan gerçeklik (sonuç değişkenindeki değişim/değer), asimetrik bir ilişkideki farklı kombinasyon koşullarının aydınlatılmasıyla ortaya çıkabilir, çünkü gerçeklik genelde birden fazla koşulda gizlidir (Woodside 2013; 2014). Ön- 
cül koşuldaki bir yüksek değer çoğu sonucu açıklamada yetersiz kalır. Örneğin Covid-19 sürecinde bir destinasyonda hijyen ve sağlık koşullarının sağlanmış olması turizm faaliyetleri için bir gereklilikken, bu durum destinasyonun tercih edilmesi için yeterli değildir. Araştırma ve gerçek hayat bağlamında, hijyen ve sağlık koşulları (öncül koşul), sonuç değişkenini öngörmede ve açıklamada yeterli değildir. Bu durumda asimetrik ilişkiler ışığında diğer çalışan kombinasyonlara bakılması yararlı olacaktır.

Çalışma, Covid-19 sürecinde seyahat niyetinin kompleks yapısını incelemek için karmaşıklık teorisinden faydalanmaktadır. Böylece, araştırmanın kavramsal modeli karmaşıklık teorisine dayalı olarak tasarlanmıştır. Karmaşık koşulların oluşturduğu olası konfigürasyonlar Şekil 1'deki Venn şemasiyla gösterilmekte ve bu anlamda ortaya çıkan koşullar ile seyahat niyeti arasındaki karmaşık nedensel ilişki görselleştirilmektedir.

\section{YÖNTEM}

Nitel karşılaştırmalı analiz (QCA), durumdan ziyade bireysel değişkenlerden oluşan konfigürasyonlar ve bu konfigürasyonları basitleştiren Boole cebri algoritması ile tüm konfigürasyonların analizini temel alır. QCA'da koşullar (bağımsız değişkenler) ve sonuç (bağımlı değişken) genellikle asimetrik ilişkiler sergiler. QCA'nın, karmaşık nedensel ilişkilerle başa çıkmada çoklu regresyondan üstün olduğu iddia edilmektedir (Rihoux ve Ragin 2009). Öncelikle, farklı faktörler arasındaki iç içe geçmiş etkileşimleri yansıtır, sonrasında sonuçları yorumlamada bağımsız değişkenlerin seviyesini inceler. Turizm gibi kaotik ve karmaşık sistemlerde, bağımsız değişkenden ziyade koşullar arasındaki karşılıklı bağımlılık yaygındır. Bu durum, koşullar ve sonuç arasındaki ortak asimetrik ilişkileri de ifade eder. QCA, büyük örneklem nicel analizinin yanı sıra küçük ve orta büyüklükteki örneklem durum çalışmalarl için de uygundur (Rihoux ve Ragin 2009).

Bu çalışmada kullanılan QCA'nın bir türü olan bulanık küme nitel karşılaştırmalı analiz (fsQCA) süreci üç bölüme ayrılabilir; doğrulama tablosunun oluşturulması, gereklilik analizi ve yeterlilik analizi. fsQCA yönteminin akış şeması olarak şu adımlar izlenir: Teorik temele dayalı olarak öncelikle sonuç ve sonrasında koşullar belirlenir. Sonuç ve koşullar fsQCA için uygun kalibrasyon denklemine göre kalibre edilir. Bu koşulların sonuç için gerekli olup olmadığını test etmek için gereklilik analizi yapılır. Gereklilik analizine göre bu kalibrasyonla birlikte bulanık küme doğrulama tablosu algoritmasindan yararlanılarak doğrulama tablosu oluşturulur. Doğrulama tablosu ile ortaya çıkacak sonuçlarla yeterlilik analizi yapılır ve son olarak fsQCA sonuçları değerlendirilir. Bu adımların ne şekilde yapılacağı bulgular ve sonuç kısmında detaylı ifade edilmektedir.

\section{Çalışma Grubu ve Ölçüm Aracı}

Veriler hazırlanan soru formu ile Google Formlar platformundan çevrimiçi toplanmıştır. Kişinin çalışmaya katılım tercihinin kendisinde olduğu, kısıtlamasız bir çevrimiçi anket ortamı olan bu

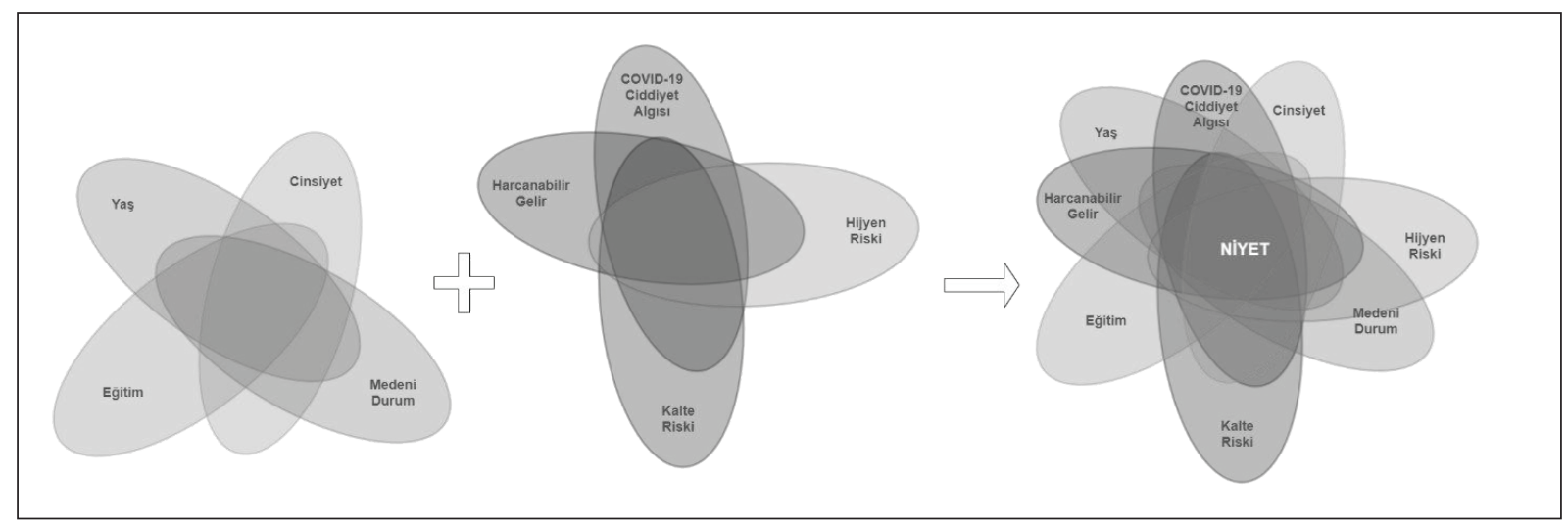

Şekil 1. Venn Şeması - Çalışmanın Asimetrik Modeli 
platform üzerinde hazırlanan anketin bağlantısı 2021 yılının Mart ayı içinde araştırmacıların profesyonel iş ve sosyal medya ağlarında paylaşılmıştır. Bu bağlamda araştırmaya gönüllü olarak katılan 349 kişi araştırmanın çalışma grubunu oluşturmaktadır. Araştırmada kullanılan soru formunun ilk bölümünde demografik sorular yer almaktadır. Katılımcılardan herhangi bir kişisel bilgi istenmemiştir (telefon numarası, e-posta, vb.). İkinci kısımda ise ilgili alanyazın ışığında hazırlanan ölçüm aracı yer almıştır. Orijinal ölçekleri oluşturan araştırmacılardan gerekli izinler alınmıştır. Buna göre ölçüm modelinde, demografik sorular hariç, toplam beş değişken yer almış ve her bir değişken üç soruyla ölçülmüştür. Sonuç değişkeni olarak seyahatten kaçınma niyeti ölçümü için Das ve Tiwari'nin (2020) seyahat niyeti ölçeği uyarlanmıştır. Temizlik ve hijyen riski, ürün fiyat ve kalite riski, turizm amaçlı harcanabilir gelir, Covid-19 ciddiyet algısı koşul değişkenlerinin ölçümü için; 'Temizlik ve Hijyen riskleri' ölçeği Pappas ve Glyptou'dan (2010) uyarlanmış ve 'Hijyen Riski' olarak kısaltılmıştır. 'Ürün Fiyat ve Kalite Riski' ölçeği ile ‘Turizm Amaçlı Harcanabilir Gelir' ölçeği Papatheodorou ve Pappas'tan (2017) uyarlanmış ve 'Kalite Riski' ile 'Harcanabilir Gelir' olarak kısaltılmışlardır. 'Covid-19 Ciddiyet Algisı' olarak adlandırılan boyut sağlık alanyazınında kullanılan algılanan hastalık ciddiyeti ölçümlerinden yola çıkılarak, araştırmanın amaçlarına özel olarak tasarlanmıştır. Algilanan ciddiyet bir hastalığa yakalanma tehlikesine ve bu durumun ciddiyetine ilişkin kişilerin düşüncelerini ölçmeye yönelik bir değişkendir. Bu bağlamda sağlık ve turizm alanında uzman akademisyenlerden görüş alınarak oluşturulan bu boyutta seyahate dair algilanan Covid-19 ciddiyeti ölçülmek istenmiştir (Tablo 1).

\section{Ölçüm Aracının Geçerlilik ve Güvenilirliği}

Ölçüm aracının dil geçerliliği için İngilizce okutmanları tarafından karşılıklı olarak (İngilizceTürkçe; Türkçe-İngilizce) çeviriler yapılmıştır. 35 kişilik bir gruba bir hafta ara ile iki kez anket uygulanmıştır. Türkçe ve İngilizce uygulamalar arasında maddeler düzeyinde korelasyon katsayılarına $(r=90, P<0,01)$ ve ilişkili grup t testi so- nuçlarına göre $(p>0,05)$ tüm sorularda dil geçerliliğinin sağlandığına yönelik kanttlar bulunmuştur.

Geçerlilik ve güvenilirlik analizleri için açımlayıcı ve doğrulayıcı faktör analizinden faydalanılmıştır. Analizler için SPSS 20 ve Smart PLS 3 programları kullanılmıştır. İç tutarlılık için Cronbach Alpha değeri hesaplanmıştır. Çalışma kapsamında yararlanılan ölçekler içindeki maddelerin faktör yüklerinin 0,50 'den büyük olması birleşme geçerliliğinin göstergesidir ( $\mathrm{Xu} \mathrm{vd}$. 2018). Bu doğrultuda faktör yükü değerleri kabul edilebilir eşiktedir. Yapı geçerliliği için incelenen Cronbach Alpha değerinin 0,70'ten, birleşik güvenilirliğin (Composite Reliability/CR) 0,70'ten ve Açıklanan Ortalama Varyansın (AVE) 0,50'den büyük olması da birleşme geçerliliği için gerekmektedir. (Xu vd. 2018). İlgili ölçeklerin boyutlarına ilişkin CR değerleri 0,80 ile 0,96; Cronbach Alpha değerleri de 0,63 ve 0,94 arasında değisşmektedir. Cronbach Alpha değeri iki ölçek için 0,70'in altında olsa da ölçeklerin genel yapısı itibariyle kabul edilebilir olarak değerlendirilebilir. Faktörlere ilişkin Açıklanan Ortalama Varyans (AVE) değerleri ise 0,62 ile 0,89 arasında değişmektedir. Bu sonuçlar, ölçeklerin var olan göstergelerinin varyansının yarısından fazlasını açıkladığını ifade etmektedir ve birleşme geçerliliğinin bir göstergesi olarak kabul edilmektedir. Ayrışma geçerliliğini göstermek, her bir yapının ortalama açıklanan varyansı, değişkenler arasındaki ikili korelâsyonların karesinden büyük olması durumunda mümkün olur. Tablo 2'de görüldügü gibi modeldeki tüm değişkenler arasındaki korelâsyonların karesi ortalama açıklanan varyans değerlerinden küçüktür ve bu ölçeklerin ayrışma geçerliliğine sahip olduğunu gösterir (Xu vd. 2018).

Çalışma kapsamında değerlendirilen ölçekler ve alt boyutlarına ilişkin korelasyon analizi sonuçları Tablo 2'de sunulmaktadır. Elde edilen sonuçlara göre; en yüksek korelasyon seyahatten kaçınma niyeti ile Covid-19 ciddiyet algısı değişkeni arasındadır.

\section{Analizler}

Demografik bulgulara göre, katılımciların yüzde 64'ü (n=225) kadın, yüzde 36'sı (n=124) erkekler- 
Tablo 1. Ölçek Maddelerinin Faktör Yük Değerleri, Geçerlilik ve Güvenilirlik Sonuçları

\begin{tabular}{|c|c|c|c|c|c|}
\hline & $\begin{array}{l}\text { Temizlik } \\
\text { ve Hijyen } \\
\text { Riski }\end{array}$ & $\begin{array}{l}\text { Ürün Fiyat } \\
\text { Kalite Riski }\end{array}$ & $\begin{array}{l}\text { Turz. Amç. } \\
\text { Harcanabilir } \\
\text { Gelir }\end{array}$ & $\begin{array}{l}\text { Covid-19 } \\
\text { Ciddiyet } \\
\text { Algısı }\end{array}$ & $\begin{array}{l}\text { Seyahatten } \\
\text { Kaçınma } \\
\text { Niyeti }\end{array}$ \\
\hline $\begin{array}{l}\text { Covid-19 nedeniyle, seyahat ederken temizlik ve hijyen } \\
\text { riskleri olduğunu düşünüyorum }\end{array}$ & 0,808 & & & & \\
\hline $\begin{array}{l}\text { Covid-19 nedeniyle, turizm bölgelerinde temizlik ve hijyen } \\
\text { riskleri olduğunu düşünüyorum }\end{array}$ & 0,912 & & & & \\
\hline $\begin{array}{l}\text { Covid-19 nedeniyle, konaklama tesislerinde temizlik ve } \\
\text { hijyen riskleri olduğunu düşünüyorum }\end{array}$ & 0,882 & & & & \\
\hline Covid-19 nedeniyle turizmde ürün fiyatları artmaktadır & & 0,725 & & & \\
\hline $\begin{array}{l}\text { Genel olarak Covid-19 gibi kriz dönemlerinde turizmde } \\
\text { ürün kalitesi düşmektedir }\end{array}$ & & 0,763 & & & \\
\hline $\begin{array}{l}\text { Covid-19 nedeniyle, tatil için yapacağım harcamanın } \\
\text { karşılığını alamayacağımı düşünüyorum }\end{array}$ & & 0,787 & & & \\
\hline $\begin{array}{l}\text { Covid-19'un gelirim üzerindeki etkisi turizm amaçlı } \\
\text { harcamalarımı olumsuz etkilemektedir }\end{array}$ & & & 0,911 & & \\
\hline $\begin{array}{l}\text { Covid-19'un istihdam güvencem üzerindeki etkisi turizm } \\
\text { amaçlı harcamalarımı olumsuz etkilemektedir }\end{array}$ & & & 0,881 & & \\
\hline $\begin{array}{l}\text { Covid-19'un bana yarattığı ekonomik maliyetler turizm } \\
\text { amaçlı harcamalarımı olumsuz etkilemektedir }\end{array}$ & & & 0,891 & & \\
\hline $\begin{array}{l}\text { Seyahat edersem Covid-19'a yakalanma riskimin yüksek } \\
\text { olduğunu düşünüyorum }\end{array}$ & & & & 0,891 & \\
\hline $\begin{array}{l}\text { Seyahat edersem Covid-19'a yakalanıp, ölmekten } \\
\text { korkuyorum }\end{array}$ & & & & 0,859 & \\
\hline $\begin{array}{l}\text { Seyahatimde Covid-19'a yakalanırsam gerekli tedaviyi } \\
\text { alamayacağımı düşünüyorum }\end{array}$ & & & & 0,563 & \\
\hline $\begin{array}{l}\text { Yakın gelecekte Covid-19 süresince, seyahat etme } \\
\text { niyetinde değilim }\end{array}$ & & & & & 0,949 \\
\hline $\begin{array}{l}\text { Yakın gelecekte Covid-19 süresince, seyahat etmeyi } \\
\text { planlamıyorum }\end{array}$ & & & & & 0,940 \\
\hline $\begin{array}{l}\text { Yakın gelecekte Covid-19 süresince, seyahat etmekten } \\
\text { kaçınıyorum }\end{array}$ & & & & & 0,937 \\
\hline Cronbach's Alpha & 0,836 & 0,631 & 0,875 & 0,696 & 0,937 \\
\hline CR & 0,902 & 0,802 & 0,923 & 0,823 & 0,959 \\
\hline Ave & 0,754 & 0,575 & 0,800 & 0,616 & 0,888 \\
\hline
\end{tabular}

den oluşurken, yüzde 54'ü ( $n=189$ ) bekar, yüzde 46 'sı ( $\mathrm{n}=160)$ evlidir. Eğitim durumları incelendiğinde katılımcılarının dağılımının ortaokul $(n=5$, yüzde 1,4$)$, lise (n=39, yüzde 11,2), ön lisans - li- sans ( $\mathrm{n}=209$, yüzde 59,9), yüksek lisans - doktora (n=96, yüzde 27,5) şeklinde olduğu görülürken, yaş dağ 1 lımının ise 17-29 ( $\mathrm{n}=113$, yüzde 32,4), 3042 ( $\mathrm{n}=178$, yüzde 51), 43-55 (n=38, yüzde 10,9), 56- 
Tablo 2. Korelasyon Tablosu

\begin{tabular}{llllll}
\hline & $\begin{array}{l}\text { Temizlik ve } \\
\text { Hijyen Riski }\end{array}$ & $\begin{array}{l}\text { Ürün Fiyat } \\
\text { Kalite Riski }\end{array}$ & $\begin{array}{l}\text { Harcanabilir } \\
\text { Gelir }\end{array}$ & $\begin{array}{l}\text { Covid-19 } \\
\text { Ciddiyet Algısı }\end{array}$ & $\begin{array}{l}\text { Seyahatten } \\
\text { Kaçınma } \\
\text { Niyeti }\end{array}$ \\
\hline Temizlik ve Hijyen Riski & 1 & & & & \\
\hline Ürün Fiyat Kalite Riski & 0,373 & 1 & 1 & 1 & 1 \\
\hline Harcanabilir Gelir & 0,159 & 0,257 & 0,203 & 0,626 & \\
\hline Covid-19 Ciddiyet Algısı & 0,517 & 0,345 & 0,212 & &
\end{tabular}

Bütün korelasyon değerleri 0,01 düzeyinde anlamlıdır

67 (n=20, yüzde 5,7) şeklinde olduğu görülmektedir.

Cinsiyet (C), medeni durum (MD), yaş (Y) ve eğitim (E) ile temizlik ve hijyen riski (HiR), ürün fiyat kalite riski (KaR), turizm amaçlı harcanabilir gelir (HaR), Covid-19 ciddiyet (CiD) algıları koşul değişkenleri olarak ele alınmaktadır. Gereklilik analizi öncesi, bulanık üyelik puanları elde etmek için kümenin üyelik derecesini kalibre etmek gerekmektedir. Üyelik puanları, teorik bilginin kapsamlı ölçüsüne ve ampirik kanıtlara dayanan kalibrasyonla belirlenir (Ragin 2014). Bulanık bir küme oluşturmak için bir aralık ölçeği değişkeni için üç niteliksel kırılma noktasının belirtilmesi gerekir; tam üyelik için eşik $(0,95)$, tam

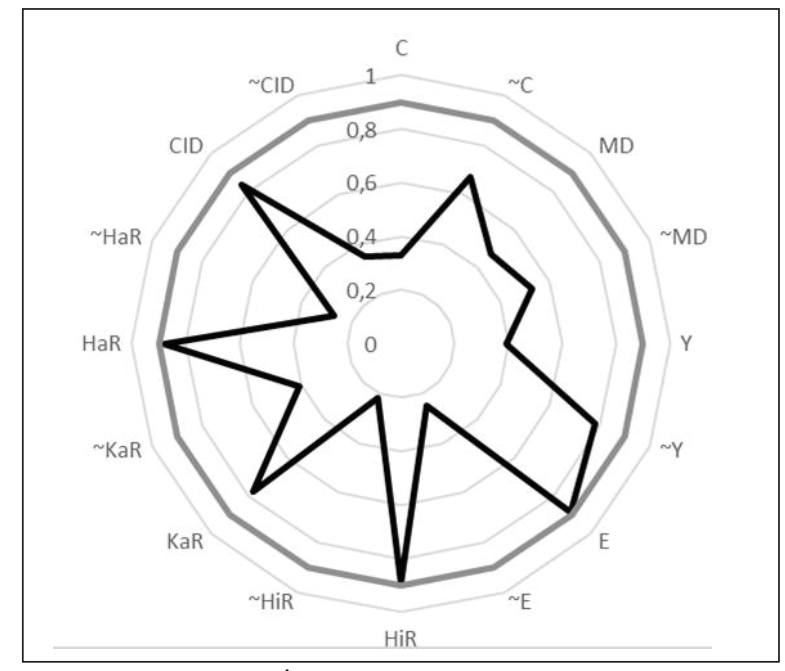

Şekil 2. Yüksek Niyet İçin Koşulların Gereklilik Analizi (siyah kalın çizgiler tutarlılığın gösterir) üye olmama eşiği $(0,05)$ ve geçiş noktası $(0,50)$ (Ragin 2008). Buna göre çalışmada yer alan 349 katılımcının profillerine göre kadın, erkek ve bekar, evli için üyelik puanları 0 ve 1 şeklinde iken eğitim durumu (E) ve yaş (Y) değişkenlerinin dört kategorisi için orijinal değerler bulanık üyelik puanlarına dönüştürülmüş ve dönüştürme üç kırılma noktasıyla gerçekleştirilmiştir. Ayrıca temizlik ve hijyen riski (HiR), ürün fiyat kalite riski (KaR), turizm amaçlı harcanabilir gelir (HaR), Covid-19 ciddiyet algisı (CiD) ve seyahatten kaçınma niyeti (niyet) de bu üç kırılmaya göre kalibre edilmiştir. Kesme noktaları analiz programı fsQCA 3.1b (Ragin 2018)'ye aktarıldıktan sonra değişkenlerinin üyelik puanlarını hesaplamak için kalibre etme işlevi kullanıldı. Örneğin, HiR için bulanık üyelik puanları; 5 için 0,95, 3 için 0,50, 1 için 0,05 ve geri kalanlar için kalibrasyon denklemiyle hesaplanan belirli bulanık puanlar verilmiştir. Daha sonra üyelik puanları için bulanık doğruluk tablosu algoritması uygulanmıştır.

\section{Gereklilik Analizi}

Koşulun sonuç değişkeni üzerinde güçlü bir şekilde bağımsız bir etki yapıp yapmadığını belirlemek için gereklilik analizi yapılmıştır. Tutarlılık puanı 0,9 eşik değerinin üzerine geçmediğinde koşul gerekli olarak etiketlenir (Ragin 2008). Şekil 2, koşullardan hiçbirinin eşik değerini geçmeyerek gereklilik testini geçtiğini göstermektedir. " $\sim$ " işareti, koşulun değerinin düşük olduğu anlamına gelir. Bu bağlamda şekle göre çalışmada 
ele alınan $\mathrm{HaR}, \mathrm{HiR}, \mathrm{KaR}, \mathrm{CiD}$ ile diğer demografik değişkenlerin koşul olarak değerlendirilmesinin seyahatten kaçınma niyeti sonucuna ulaşmak adına gerekli olduğu ifade edilebilir.

\section{Doğrulama Tablosu}

Mantıksal olarak mümkün olan tüm konfigürasyonların bir listesi doğruluk tablosunda yer alırken, ampirik gözlemler genellikle mantıksal konfigürasyonlardan daha azdır ve gözlemlenmeyen durumlar mantıksal kalanlar olarak tanımlanır. Frekans kesme, bir konfigürasyonun geçerli olduğu örneklerin sayısını ifade eder ve örnek boyutu yeterince büyük olduğunda uygun şekilde ayarlanabilir (Rihoux ve Ragin 2009). Çalışmada iki olarak ele alınmıştır. Tutarlılık kesme, aynı sonucu yönlendiren konfigürasyonların yüzdesini ifade eder (Ragin 2014) ve 0,80'e göre ayarlanmıştır. Kesme gereksinimlerini karşılamayan kalıntılar ve satırlar doğruluk tablosundan silinmiş ve çelişkili yapılandırmanın (Rihoux ve Ragin 2009) doğrulama tablosunda görünmemesi sağlanmıştır.

\section{Yeterlilik Analizi}

Sonuçla güvenilir bir şekilde ilişkilendirilen konfigürasyonlar, yeterlilik analizinde gösteril- mektedir. Çözüm kapsamı, sonuçlara göre numunelerin kapsamını temsil etmektedir. Çözüm tutarlılığı, genellikle 0,8 ve üstünde ise sonuç ile koşullar arasındaki tutarlılık derecesini ifade etmektedir (Fiss 2011). Çözüm kapsamı, tüm çözümlerin kapsadığı sonuç örneklerinin yüzdesini ölçmektedir (Rihoux ve Ragin 2009). Yüksek niyet için ara çözümün sonuçları Tablo 3'te gösterildiği gibi yazılımla (fsQCA 3.1b) elde edilmiştir. Bir koşul adının varlığı, değerinin yüksek olduğu veya 1 için verildiği; yokluğun düşük olduğu veya 0 için verildiği şeklinde yorumlanabilir. Çözüm tutarlılığı, güçlü bir açıklama gücü anlamına gelen 0,877'e ulaşırken çözüm kapsamı, tüm konfigürasyonların 194 sonuç vakasını 0,761 gibi bir değerle kapsaması modelin kabul edilebilir olduğunu göstermektedir. Ayrıca, yedi konfigürasyon için tutarlılık değerleri $0,80^{\prime}$ den yüksektir.

\section{BULGULAR}

Asimetrik ilişkiler incelendiğinde seyahatten kaçınma niyetini etkileyen 7 konfigürasyon oluştuğu görülmektedir. 2. konfigürasyon incelendiğinde $\left(E^{*} \mathrm{HiR}^{*} \mathrm{KaR}{ }^{*} \mathrm{HaR}{ }^{*} \mathrm{CiD}\right)$ araştırma modeline dahil edilen bütün demografik dışı koşul değiş̧kenlerinin (temizlik ve hijyen riski, ürün fiyat ve

Tablo 3. Seyahatten Kaçınma Niyeti İçin Koşulların Yeterli Konfigürasyonları

\begin{tabular}{|c|c|c|c|c|c|c|c|}
\hline & & & Neden & nfigüra & Sonuç) & & \\
\hline & & & & Niyet & & & \\
\hline & 1 & 2 & 3 & 4 & 5 & 6 & 7 \\
\hline Cinsiyet & $\otimes$ & & $\otimes$ & $\otimes$ & $\bullet$ & $\otimes$ & \\
\hline Medeni Durum & $\otimes$ & & $\otimes$ & & $\bullet$ & $\otimes$ & $\bullet$ \\
\hline Yaş & $\otimes$ & & $\otimes$ & $\otimes$ & $\otimes$ & & \\
\hline Eğitim & $\bullet$ & $\bullet$ & $\bullet$ & $\bullet$ & $\bullet$ & $\bullet$ & $\bullet$ \\
\hline Temz. Hijyen Riski & $\bullet$ & $\bullet$ & & $\bullet$ & $\bullet$ & $\bullet$ & $\bullet$ \\
\hline Ür. Fiyat Kalite Riski & & $\bullet$ & $\otimes$ & $\bullet$ & & $\otimes$ & \\
\hline Harcanabilir Gelir & & $\bullet$ & $\bullet$ & $\otimes$ & $\bullet$ & $\bullet$ & $\bullet$ \\
\hline Covid-19 Ciddiyeti & & $\bullet$ & & & & $\otimes$ & $\bullet$ \\
\hline Tutarlılık & 0,849 & 0,938 & 0,905 & 0,938 & 0,879 & 0,883 & 0,935 \\
\hline Çözüm Kapsamı & & & & 0,761 & & & \\
\hline Çözüm Tutarlıığı & & & & 0,877 & & & \\
\hline
\end{tabular}


kalite riski, turizm amaçlı harcanabilir gelir ve Covid-19 ciddiyeti) seyahatten kaçınma davranışını etkilediği görülmektedir. Bu durum tasarlanan modelin tutarlı olduğuna ve katılımcılar için Covid-19 özelinde seyahati engelleyen risklerin demografik koşullar ne olursa olsun var olduğuna işaret etmiştir.

Konfigürasyon $1\left(\sim C^{*} \sim M D^{*} \sim Y^{*} E^{*} H i R\right)$, $3\left(\sim C^{*} \sim M D^{*} \sim Y^{*} E^{*} \sim K a R^{*} \mathrm{HaR}\right)$ ve 4 $\left(\sim C^{*} \sim Y^{*} E^{*} H i R^{*} K a R^{*} \sim H a R\right)^{\prime}$ 'e göre orta yaş altı kadınların seyahatten kaçınmasında 3 koşul etkili olabilmektedir. Sadece yüksek hijyen riski seyahatten kaçınma için yeterli olabilirken (konf. 1), harcanabilir gelir riski yüksek, ürün fiyat-kalite riski düşük kadınların (konf. 3) ve hijyen riski yüksek, ürün fiyat-kalite riski yüksek, harcanabilir gelir riski düşük kadınların (konf. 4) seyahatten kaçındıkları görülmektedir. Bu koşullar kadınlar için genel olarak temizlik ve hijyen risklerinin yüksek olduğuna işaret etmiştir. Erkekler bağlamında ortaya çıkan 5. konfigürasyon ise $\left(C^{*} M D^{*} \sim Y^{*} E^{*} H i R^{*} H a R\right)$ evli erkeklerin hijyen riskleri ve turizm amaçlı harcanabilir gelir risklerinin yüksek olması durumunda seyahatten kaçınma davranışı sergileyebileceklerini göstermiştir. Evli erkekler için hijyen riskleri ve pandeminin olumsuz ekonomik etkileri seyahati kısitlayabilmektedir.

7. konfigürasyona göre $\left(M D^{*} E^{*} \mathrm{HiR}^{*} \mathrm{HaR}^{*} \mathrm{CiD}\right)$ hijyen, harcanabilir gelir ve Covid-19 ciddiyet algıları yüksek evlilerin seyahatten kaçınma davranışları sergileyebileceği görülmüştür. Bu durum evli katılımcıların Covid-19'u yüksek riskleri olan bir tehdit olarak gördükleri ve ekonomik anlamda olumsuz etkilendikleri şeklinde yorumlanabilir. 6. konfigürasyonda $\left(\sim C^{*} \sim M D^{*} E^{*} H i R^{*} \sim K a R^{*} H a R^{*} \sim C i D\right)$ ise hijyen ve harcanabilir gelir risk algıları yüksek, ürün-fiyat kalite riski ve ciddiyet algıları düşük kadınların seyahatten kaçındıkları görülmüştür. 1., 3. ve 6 . konfigürasyonların bekar kadınların risk algılarını gösterdiği ve 3 koşulda da Covid-19 hastalık ciddiyet algısının düşük veya yok ve ürünfiyat kalite riskinin düşük veya yok olduğu görülmüştür. Bu koşullar bekar kadınlar için genel Covid-19 hastalık ciddiyeti ve turistik ürünlerin fiyatlarının yükseldiğine dair algıların zayıf olduğunu göstermektedir.

\section{SONUÇ, TARTIŞMA VE ÖNERILER}

Covid-19 kriz süreci turistin düşünce ve zihin yapısını etkilemekte, seyahat kararlarında davranışsal bir değişimi beraberinde getirmektedir (Kock vd. 2020). Belirsizliğin ve öngörülemeyen ilişkilerin hâkim olduğu kriz dönemlerinde doğrusal yöntemlerin karmaşık ilişkileri açıklamada yetersiz kaldığg görülmektedir. Bu yüzden, farklı açıklama düzeyleri sunan, düzeni ve düzensizliği birlikte ele alan karmaşıklık paradigması gibi alternatif yöntemler önemsiz veya normal d1şı olarak değerlendirilen koşulların ve çıktıların fark edilmesini sağlayabilir. Sonuçlardaki büyük değişim koşulların düşük düzeylerinde saklı olabilir. Ayrıca karmaşıklık paradigmasının geleneksel tüketici karar verme modellerine dayanan turist karar verme süreçlerine alternatif bir bakış açısı sunabileceği düşünülmektedir.

Beklenen fayda teorisi, gerekçeli eylem teorisi, planlı davranış teorisi ve çeşitli çoklu karar verme modellerinin temel oluşturduğu tüketici karar verme modelleri (Sirakaya ve Woodside 2005), turizm bağlaminda fonksiyonel fayda ve tatmin arayışında olan turist karar verme modellerine evrilmiştir. Ancak kişilik tipleri, tutumlar, inançlar gibi psikolojik faktörlerin ve diş koşulların etkisiyle alternatif destinasyonlar arasında bir seçim yapmaya çalışan turist için kaotik dönemde karar verme süreci daha farklı işlemektedir. Genel olarak riskli dönemlerde turist için güvende olma hissi ve risk algıları destinasyon tercihinin belirleyicileri olmaktadır. Nitekim Reisinger ve Mavondo (2005) seyahate dair risk algilarıyla seyahat kaygısı arasında güçlü ilişkiler olduğunu söylemiş ve turist karar verme çalışmalarına kültürel ve psikografik faktörlerin, risk türlerinin, kaygının, güvensizlik algısının dahil edilmesini önermiştir. Potansiyel risk algılarının farklı değişkenlerle ilişkisine odaklanmak kriz dönemindeki seyahat davranışına ışık tutabilir.

Araştırma sonuçlarına göre, nedensel konfigürasyon tablosu incelendiğinde temizlik ve hijyen riskleri 6 konfigürasyonda yüksek düzeyde belirmiş, turizm amaçlı harcanabilir gelir ise biri düşük, 5'i yüksek düzey toplam 6 konfigürasyonda görülmüştür. Covid-19'un insanların gelirleri ve iş güvenceleri üzerindeki olumsuz etkileri tu- 
rizm faaliyetlerinden kaçınmalarına yol açmaktadır. Pandemi sürecinde fiyatların artması ve bunun paralelinde insanların gelirinin azalması turizm amaçlı harcanabilir gelirde düşüşe yol açmaktadır.

Bununla birlikte, pandemi nedeniyle seyahat sirasinda, destinasyonda veya konaklama tesislerinde temizlik ve hijyen riskleri olabileceğini düşünen katılımcılar seyahatten yüksek oranda kaçınmaktadır. Bu anlamda katılımcılar üzerinde pandemi sürecinin yarattığ tablonun ve hastalık riski sebebiyle oluşan hijyen kaygılarının etkisi görülmektedir. Hijyen kaygısı ve hastalıktan kaçınma davranışları alanyazındaki diğer çalışmalar tarafından da desteklenmektedir (Cahyanto vd. 2016; Pappas ve Glyptou 2021). Nitekim, dünya genelinde ülkelerin aşılama programları başlatması, seyahat için aşı pasaportlarının gündeme gelmesi, güvenli seyahat koridorları oluşturulması ve güvenli turizm sertifikaları hastalık bulaşma riskine karşı alınmaya çalışılan güncel önlemler olarak sıralanabilir.

Araştırma kapsamında, pandeminin yaratt1$\breve{g} 1$ şartlar sebebiyle turistlerde temizlik ve hijyen kaygıları oluşması ve turizm amaçlı gelirin olumsuz etkilenmesiyle birlikte, turistik ürünlerde fiyat ve kalite riskleri oluşacağ 1 ve turistlerde Covid-19'a dair ciddiyet algisıyla birlikte seyahatten kaçınma niyetinin oluşabileceği öngörülmektedir. Bu doğrultuda bulgular kısmında açıklanan konfigürasyonlarda bu koşulların desteklendiği görülmektedir. Pandemi sebebiyle turizm ürün kalitesinin düşme riski yüzünden (örn. konaklama tesislerinde bazı hizmetlerin verilmemesi, yeme-içme işletmelerinde sınırlı ürün arzı gibi) turistler tatil için yapacakları harcamanın karşılığını alamayacağını düşünmektedir. Fiyat ve kalite riskleri, gerçek riskler yerine, aslında bir parça tüketicinin zihninde algıladığı risklerdir. Pandemi koşulları sebebiyle turistik ürün kalitesinde düşüşler olacağını düşünen turistlerin seyahatten kaçınma davranışı sergileyebileceği saptanmıştır. Araştırma kapsamında tasarlanan Covid-19 ciddiyet algısı bizlere turistlerin seyahat sirasinda Covid-19'a yakalanma risklerinin olduğunu ve gittikleri destinasyonda gerekli tedaviyi alamayacaklarını düşündüklerini gös- termektedir. Covid-19 ciddiyet alg1si turistlerin seyahat ettikleri destinasyonda, olası bir semptom durumunda gerekli sağlık hizmetlerini sağlayacak altyapının oluşturulmasını beklediğine işaret etmektedir. Güvenli turizm sertifikası bu anlamda algılanan Covid-19 ciddiyetini düşürmeye yardımcı olabilir (https://tga.gov.tr/).

fsQCA koşul ve sonuç değişkenlerinin asimetrik ilişkilerinin farklı bağlamlarda görülebilmesini mümkün kılmaktadır. Bu bakımdan yedi yeterlilik konfigürasyonuna göre ön lisans ve üzeri eğitim düzeyindeki katılımcıların çeşitli seyahat riskleri algıladığı ve seyahatten kaçındığı görülmüştür. Bu durum eğitim düzeyi yüksek olan katılımcıların risk algılarının daha yüksek olduğu şeklinde yorumlanabilir. Das ve Tiwari'nin (2020) çalışmasında gezginlerin Covid-19 algısının eğitim düzeylerine göre farklılaşmadığı; ancak hastalığı önleyici önlemler alma adına yüksek düzeyde eğitimli gezginlerin daha istekli olduğu saptanmıştır. Cinsiyet, eğitim düzeyi, yaş ve medeni durum bağlamında farklı konfigürasyonlar farklı hassasiyetlere dikkat çekmektedir.

Covid-19 krizi, etkileri bakımından turizm endüstrisine, turizm araştırmacılarına ve profesyonellerine küresel değişimin etkileri hakkında önemli çıtılar sunmaktadır (Gössling vd. 2021: 15). Farklı ilişkisel ağları ve düzeyleri açığa çıkarabilen fsQCA gibi alternatif yöntemler kriz süreçlerinde sektörün esnekliğini arttırmaya yardımcı olabilir. Kaos ve karmaşıklıktan hareket eden, krizleri doğanın ve yaşamın bir parçası olarak gören bir bakış açısı turizmin kriz dönemlerindeki ihtiyaçlarına daha yapıcı çözümler sunacaktır. Nitekim araştırma bulguları ışı̆̆ında, turist karar verme sürecinin karmaşıklığının asimetrik ilişkilerle açıklanabildiği görülmüştür. Konfigürasyonlar farklı demografide turistlerin farklı risk hassasiyetlerine işaret etmektedir. Buna göre yerli turistlerin risk algılarının belirlenmesinde ve 'krize dayanıklı turist' sinıflandırmasına (1) temizlik ve hijyen riskleri, (2) turizm amaçlı harcanabilir gelir, (3) ürün fiyat ve kalite riskleri, (4) Covid-19 ciddiyeti temel oluşturabilir. Bununla birlikte hastalık veya kriz bağlamında, turistlerin ne tür risk azaltıcı davranışlarda bulunduğu araştırılabilir ve farklı risk algılarıyla 
seyahat davranışı arasındaki ilişkilerin nasıl şekillendiği incelenebilir.

Araştırma sonuçlarını yorumlarken araştırmanın kısıtlarından bahsetmek gelecekteki çalışmalara yol gösterecektir. Bu bağlamda araştırmanın bulguları yerli turistlerden oluşan bir çalışma grubu üzerinden yorumlanmıştır. Uluslararası turistler veya daha küçük ve özel örneklemler üzerinde yapılacak çalışmalar farklı risk algılarını ortaya çıkarıp alternatif, daha geçerli risk ve seyahat davranışı modelleri oluşturabilir. $\mathrm{Bu}$ bağlamda turizm alanında nispeten yeni bir yöntem olan fsQCA, turistlerin farklı demografik ve risk koşullarını ortaya çıkarmaya yardımcı olabilir. Turizm alanyazınının krizler ve bu dönemlerdeki turist davranışı üzerine eğilmesi krize dayanıklı bir sektör oluşmasına yardımcı olacaktır. Bu açıdan akademik çalışmaların sağlık ve tıp gibi alanlarla çok disiplinli bakış açısıyla yürütülmesi önerilmektedir. Ayrıca sadece hastalıklar üzerine değil, doğal afetler, terör, finansal riskler gibi farklı kriz türleri üzerine çalışmalar yapılması esnek ve dayanıklı turizm kavramına yaklaşmamız1 sağlayacaktır.

\section{KAYNAKÇA}

AON (2020). Decision Making in Complex \& Volatile Times : Keys to Managing COVID-19, https://www.aon. com/getmedia/86577ac3-1ce2-43eb-8323-1a1191488355/ Decision-Making-in-Complex-and-Volatile-Times-Keysto-Managing-COVID-19-2020-05-06.aspx (Erişim tarihi: 09.01.2021).

Cahyanto, I., Wiblishauser, M., Pennington-Gray, L. ve Schroeder, A. (2016). The Dynamics of Travel Avoidance: The Case of Ebola in the U.S., Tourism Management Perspectives, 20: 195-203.

Das, S. S. ve Tiwari, A. K. (2020). Understanding International and Domestic Travel Intention of Indian Travellers During COVID-19 Using a Bayesian Approach, Tourism Recreation Research, 1-17.

Doll, W. E. (2008). Chaos and Complexity Theories. İçinde; L. M. Given (Editör), The Sage Encyclopedia of Qualitative Research Methods (ss. 75-78). Thousand Oaks, Kaliforniya: SAGE Yayınları.

Faulkner, B. (2001). Towards a Framework for Tourism Disaster Management, Tourism Management, 22 (2): 135-147.

Fiss, P. C. (2011). Building Better Causal Theories: A Fuzzy Set Approach to Typologies in Organization Research, Academy of Management Journal, 54 (2): 393-420.

Gössling, S., Scott, D. ve Hall, C. M. (2021). Pandemics, Tourism and Global Change: A Rapid Assessment of COVID-19, Journal of Sustainable Tourism, 29 (1): 1-20.
Hajibaba, H., Gretzel, U., Leisch, F. ve Dolnicar, S. (2015). Crisis-resistant Tourists, Annals of Tourism Research, 53: 4660.

Huang, X., Dai, S. ve Xu, H. (2020). Predicting Tourists' Health Risk Preventative Behaviour and Travelling Satisfaction in Tibet: Combining the Theory of Planned Behaviour and Health Belief Model, Tourism Management Perspectives, 33: 100589.

Karabulut, G., Bilgin, M. H., Demir, E., ve Doker, A. C. (2020). How Pandemics Affect Tourism: International Evidence, Annals of Tourism Research, 84: 102991.

Kock, F., Nørfelt, A., Josiassen, A., Assaf, A. G. ve Tsionas, M. G. (2020). Understanding the COVID-19 Tourist Psyche: The Evolutionary Tourism Paradigm, Annals of Tourism Research, 85: 103053.

Kozak, M., Crotts, J. C. ve Law, R. (2007). The Impact of the Perception of Risk on International Travellers, International Journal of Tourism Research, 9 (4): 233-242.

Lorenz, E. N. (1993). The Essence of Chaos. Londra: UCL Press.

Manson, S. M. (2001). Simplifying Complexity: A Review of Complexity Theory, Geoforum, 32 (3): 405-414.

Neuburger, L. ve Egger, R. (2020). Travel Risk Perception and Travel Behaviour During the COVID-19 Pandemic 2020: A Case Study of the DACH Region, Current Issues in Tourism, 1-14.

Papatheodorou, A. ve Pappas, N. (2017). Economic Recession, Job Vulnerability, and Tourism Decision Making: A Qualitative Comparative Analysis, Journal of Travel Research, 56 (5): 663-677.

Pappas, N. ve Glyptou, K. (2021). Accommodation Decisionmaking During the COVID-19 Pandemic: Complexity Insights From Greece, International Journal of Hospitality Management, 93: 102767.

Ragin, C. C. (2008). Redesigning Social Inquiry: Fuzzy Sets and Beyond. Şikago: University of Chicago Press.

Ragin, C. C. (2014). The Comparative Method: Moving Beyond Qualitative and Quantitative Strategies With a New Introduction. Kaliforniya: University of California Press.

Ragin, C. C. (2018). User's Guide to Fuzzy-Set/Qualitative Comparative Analysis 3.0. Kaliforniya: University of California.

Reddy, M. V., Boyd, S. W. ve Nica, M. (2020). Towards a Postconflict Tourism Recovery Framework, Annals of Tourism Research, 84: 102940.

Reisinger, Y. ve Mavondo, F. (2005). Travel Anxiety and Intentions to Travel Internationally: Implications of Travel Risk Perception, Journal of Travel Research, 43 (3): 212-225.

Rihoux, B. ve Ragin, C. C. (2009). Configurational Comparative Methods. Qualitative Comparative Analysis (QCA) and Related Techniques. Kaliforniya: Sage.

Ritchie, B. W. ve Jiang, Y. (2019). A Review of Research on Tourism Risk, Crisis and Disaster Management: Launching the Annals of Tourism Research Curated Collection on Tourism Risk, Crisis and Disaster Management, Annals of Tourism Research, 79: 102812.

Russell, R. ve Faulkner, B. (1999). Movers and Shakers: Chaos Makers in Tourism Development, Tourism Management, 20 (4): 411-423. 
Sirakaya, E. ve Woodside, A. G. (2005). Building and Testing Theories of Decision Making by Travellers, Tourism Management, 26 (6): 815-832.

Sönmez, S. F. ve Graefe, A. R. (1998). Determining Future Travel Behavior From Past Travel Experience and Perceptions of Risk and Safety, Journal of Travel Research, 37 (2): 171-177.

Woodside, A. G. (2013). Moving Beyond Multiple Regression Analysis to Algorithms: Calling for Adoption of a Paradigm Shift From Symmetric to Asymmetric Thinking in Data Analysis and Crafting Theory, Journal of Business Research, 66: 463-472.
Woodside, A. G. (2014). Embrace Perform Model: Complexity Theory, Contrarian Case Analysis, and Multiple Realities, Journal of Business Research, 67 (12): 2495-2503.

Xu, Z., Zhang, K., Min, H., Wang, Z., Zhao, X. ve Liu, P. (2018). What Drives People to Accept Automated Vehicles? Findings From a Field Experiement, Transportation Research Part C: Emerging Technologies, 95: 320-334.

Zenker, S. ve Kock, F. (2020). The Coronavirus Pandemic-A Critical Discussion of a Tourism Research Agenda, Tourism Management, 81: 104164.
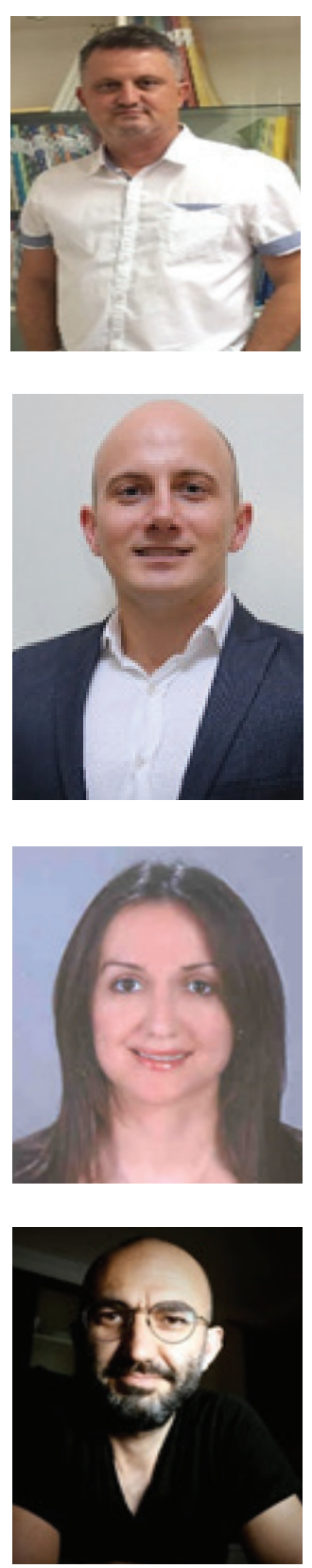

Beykan ÇizEL

Ihsan Doğramacı Bilkent Üniversitesi, Turizm ve Otel İşletmeciliği Bölümü'nden mezun oldu (1996). Yüksek lisans derecesini Akdeniz Üniversitesi'nden Turizm ve Otelcilik Dalı'ndan (1999), doktora derecesini de Akdeniz Üniversitesi'nde İşletme Dalı'ndan aldı (2005). Akdeniz Üniversitesi'nde çalışmaya başladı (1996). Doçentlik unvanını ise İşletme Bölümü Yönetim ve Organizasyon Anabilim Dalı'ndan aldı (2010). Halen Akdeniz Üniversitesi Turizm Fakültesi'nde profesör olarak görev yapmaktadır. Temel çalışma alanları, turizm ve otel işletmeciliği, sosyal psikoloji ve e-turist davranışıdır.

İsmail Gökay KIRTIL

Doğu Akdeniz Üniversitesi, Turizm Fakültesi, Turizm ve Otel İşletmeciliği Bölümü’nden mezun oldu (2010). Yüksek lisans derecesini Akdeniz Üniversitesi'nden Turizm İşletmeciliği ve Otelcilik Dalı'ndan aldı (2019). Aynı yıl Akdeniz Üniversitesi, Turizm İşletmeciliği Dalı'nda doktora eğitimine başladı. Özel sektör kariyerine Royal Caribbean Cruise Line firmasında yaz stajı yaparak başladı (2010). The Marmara Collection Grubu'nda çalıştı (2011-2018). Ardından Akdeniz Üniversitesi Demre Dr. Hasan Ünal Meslek Yüksek Okulu'nda öğretim görevlisi olarak çalışmaya başladı (2018). Halen Akdeniz Üniversitesi Demre Dr. Hasan Ünal Meslek Yüksek Okulu'nda görev yapmaktadır. Temel çalışma alanları gönüllülük faaliyetleri, turist davranışı ve e-turizmdir.

\section{Rabia BATO ÇIZEL}

Akdeniz Üniversitesi Turizm İşletmeciliği Bölümü’nden mezun oldu (1999). Yüksek lisans derecesini Akdeniz Üniversitesi Turizm İşletmeciliği ve Otelcilik Yüksekokulu'ndan (2002), doktora derecesini de Akdeniz Üniversitesi İşletme Bölümü'nden aldı (2008). Akdeniz Üniversitesi'nde çalışmaya başladı (2001). Doçentlik unvanını İşletme bölümü Yönetim ve Organizasyon Anabilim Dalı́ndan aldı (2013). Halen Akdeniz Üniversitesi İktisadi ve İdari Bilimler Fakültesi'nde profesör olarak görev almaktadır. Temel çalışma alanları, insan kaynakları yönetimi, yönetim ve organizasyon, çalışma psikolojisidir.

\section{Volkan AŞKUN}

Hacettepe Üniversitesi Fizik Mühendisliği'nden mezun oldu (2010). Ankara Üniversitesi İnsan Kaynakları Yönetimi ve Kariyer Danışmanlığı (2015) ve Akdeniz Üniversitesi Çalışma Ekonomisi ve Endüstri İlişkileri Bölümlerinden yüksek lisans derecelerini aldı (2018). Sosyal Politika ve Çalışma Iliş̧ileri doktora programına devam etmektedir (2018-). Turizm ağılıklı özel sektörde IKY, Organizasyon ve Proje Yöneticisi gibi unvanlarda çalıştı (20102018). Akdeniz Üniversitesi'nde öğretim görevlisi olarak çalışmaktadır (2020-). Temel çalışma alanları endüstri ve örgüt psikolojisi, sosyal politika ve karmaşıklıktır. 